\title{
Resurrection in Paganism and the Question of an Empty Tomb in 1 Corinthians 15*
}

\author{
JOHN GRANGER COOK \\ Religion and Philosophy, LaGrange College, 601 Broad St., LaGrange, GA 30240, \\ USA.Email: jcook@lagrange.edu
}

On the basis of the semantics of óví $\tau \eta \mu \mathrm{t}$ and $\dot{\varepsilon} \gamma \varepsilon \dot{\rho} \rho \omega$ and the nature of resurrected bodies in ancient Judaism and ancient paganism, one can conclude that Paul could not have conceived of a resurrection of Jesus unless he believed the tomb was empty.

Keywords: 1 Cor $15.3-5$, empty tomb, resurrection in paganism

Wilhelm Bousset, one of the original members of the religionsgeschichtliche Schule, in his discussion of 1 Cor 15.3-5, wrote: 'Here it is now extraordinarily important that the Apostle says nothing either concerning the empty tomb or concerning the witness of the women about the empty tomb. What he does not say, one cannot wish to read between the lines. ${ }^{\prime 1}$ This is an argumentum ex silentio and as such is logically invalid. Nevertheless, Bousset's approach has become programmatic for many scholars in the discipline. ${ }^{2}$ My thesis is that Paul could not have conceived of a resurrection of Jesus unless he believed his tomb was empty. The intention of the article is certainly not to prove the historicity of the empty tomb - a pointless exercise after the arguments of David Hume. ${ }^{3}$

The argument schema for the thesis is as follows:

* I am grateful for comments on the article made by the NTS reviewer, by historians of religion Jan Bremmer and Jorunn Jacobsen Buckley, and by philosopher Ian Morton. At the 2015 SBL meeting in Atlanta, I read an earlier version in the Corpus Hellenisticum Novi Testamenti section. Abbreviations for Latin texts below are from the $O L D$ and A. Blaise's Dictionnaire latin-français des auteurs chrétiens. Abbreviations for Greek patristic texts are from LPGL.

1 W. Bousset, 'Der erste Brief an die Korinther', Die Schriften des Neuen Testaments neu übersetzt und für die Gegenwart erklärt: Zweiter Band. Die Briefe. Die johanneischen Schriften (ed. J. Weiss; Göttingen, 1908) 72-161, esp. 146.

2 See J. Ware, 'The Resurrection of Jesus in the Pre-Pauline Formula of 1 Cor 15.3-5', NTS 60 (2014) 475-98, esp. 477-9, for a survey of similar views.

3 D. Hume, 'Of Miracle', Philosophical Essays Concerning Human Understanding (London: Millar, 1748) 173-203. 
1. $\dot{\alpha} v i \sigma \tau \eta \mu$ and $\dot{\gamma} \gamma \varepsilon i \rho \omega$, when used to describe resurrection, imply a physical movement upward.

2. In ancient Judaism (from the second century BCE on), the existing evidence demonstrates that individuals viewed resurrection as physical (i.e. bodily). Clearly some ancient Jews believed in other versions of the afterlife such as the immortality of the soul or the future exaltation of the spirit.

3. In ancient paganism, texts from classical Greece, the Roman Republic and the Empire all envisioned cases of resurrection as physical.

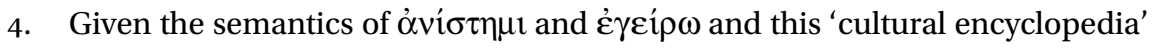
of resurrection, one can conclude that Paul and his readers, Jewish or pagan, would have assumed that a tradition about the burial of Christ and his resurrection on the third day presupposed an empty tomb.

\section{Some Methodological Reflections}

By 'physical resurrection' I mean a resurrection in which the body of a dead individual returns to life in some sense (e.g. a return to mortal life or immortal life). 'Physical' or 'bodily resurrection' is consistent with a transformation of the earthly body (e.g. into a $\sigma \hat{\omega} \mu \alpha \pi v \varepsilon v \mu \alpha \tau \iota \kappa o ́ v)$. The evidence, by necessity, for resurrection in paganism is from widely diverse chronological eras and appears in diverse contexts in the authors who preserve the traditions. Nevertheless, one can discern patterns in the pagan narratives of resurrections that are clearly analogous to resurrection in ancient Judaism and early Christianity. Jonathan Z. Smith's distinction between analogy and genealogy ${ }^{4}$ in the history of religions can serve to illuminate the comparisons to be made below: they are analogies and not genealogies. My goal is not, for example, to demonstrate pagan influence (a genealogical method) on Paul and early Christianity or vice versa. In the discussion of Greco-Roman divinities below I have dispensed with the concept of the annual resurrection of vegetation deities. ${ }^{5}$

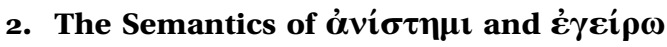

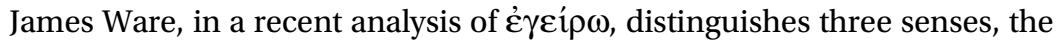
first two of which are closely related: (1) 'awaken, raise from sleep' or 'wake up, rise from sleep'; (2) 'rouse up, stir up'; and (3) 'raise up, set up right' or 'rise

4 J. Z. Smith, Drudgery Divine: On the Comparison of Early Christianities and the Religions of Late Antiquity (Chicago: University of Chicago Press, 1990) 47-51, 114, 118. On genealogy cf. also J. Bremmer, 'The Resurrection between Zarathustra and Jonathan Z. Smith', NedThT 50 (1996) 89-107 (slightly expanded in idem, The Rise and Fall of the Afterlife (London/New York: Routledge, 2002) 41-55).

5 Cf. J. Z. Smith, 'Dying and Rising Gods', ER 4 (2005) 2535-40 and idem, Drudgery Divine, 90-3. 
up, stand upright'. ${ }^{6}$ In the first and third senses 'the basic semantic meaning of getting up or arising to stand is present'. ${ }^{7}$ This seems correct in general, although

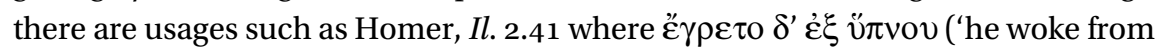
sleep') is followed by $\varepsilon \check{\zeta} \varepsilon \tau$ o $\delta$ ' o $\rho \theta \omega \theta \varepsilon i \zeta$ in 2.42 ('he sat up straight'). In such a text, one cannot demonstrate that the meaning 'arising to stand' is necessarily

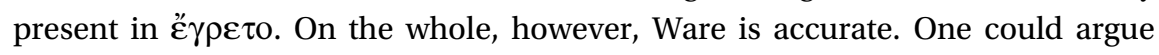

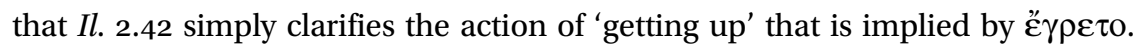

A text (probably first or early second century $\mathrm{CE}$ ) attributed to Ammonius the

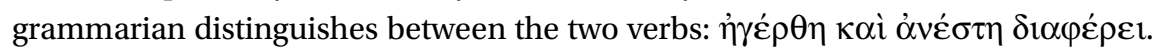

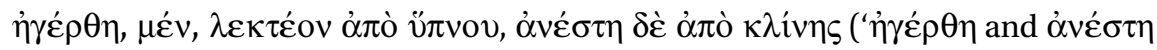
differ. 'H $\mathrm{\gamma} \dot{\varepsilon} \rho \theta \eta$ (he/she rose) is, on the one hand, to be said "from sleep", but

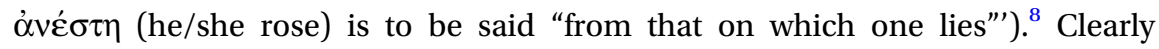
Ammonius perceives a physical meaning in both verbs. In another text,

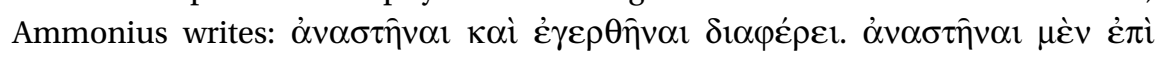

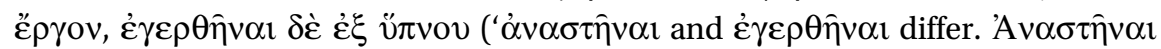
is, on the one hand, to rise for a task, but $\dot{\varepsilon} \gamma \varepsilon \rho \theta \hat{\eta} v \alpha$ is to rise from sleep'). ${ }^{9}$ In

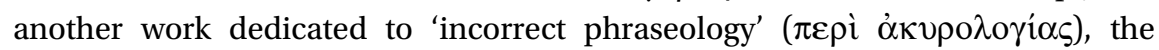

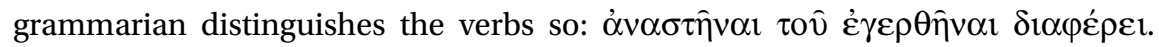

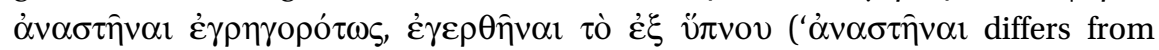

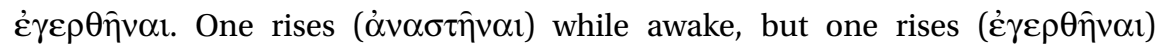

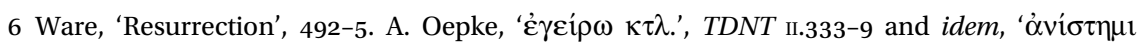
$\kappa \tau \lambda$. , , TDNT I.368-72 devotes minimal attention to resurrection in paganism (the same is true of Oepke's 'Auferstehung II (des Menschen)', RAC I (1950) 930-8). G. Bertram, 'Auferstehung I (des Kultgottes)', RAC I (1950) 919-30 uses the concept (now mostly abandoned) of the resurrection of a vegetation god. The finest linguistic survey of resurrection in paganism is still E. Fascher, 'Anastasis-Resurrectio-Auferstehung: Eine programmatische Studie zum Thema "Sprache und Offenbarung"', ZNW 40 (1941) 166-229. A. J. M. Wedderburn (Baptism and Resurrection: Studies in Pauline Theology against its GraecoRoman Background (WUNT 44; Tübingen: Mohr Siebeck, 1987) surveyed the resurrections of certain gods, but was not concerned with linguistic analysis. D. Ø. Endsjø, Greek Resurrection Beliefs and the Success of Christianity (New York: Palgrave Macmillan, 2009) has a large collection of references, but did few linguistic investigations and conflated resurrection with translation (individuals who have not died, or who are on funeral pyres, whose bodies are taken up to heaven or immortalized). R. C. Miller, Resurrection and Reception in Early Christianity (New York/London: Routledge, 2015) focuses on 'translation fables' and passes over resurrection traditions in antiquity.

7 Ware, 'Resurrection', 494.

8 [Ammonius], De adfinium vocabulorum differentia §216 (BT 56.15-16 Nickau). Cf. K. Nickau, ed., Ammonii qui dicitur De adfinium vocabulorum differentia (BT; Leipzig: Teubner, 1966) lxvi-lxvii on the date of the text (attributed to three different authors: Ammonius, Herrenius Philo, and Ptolemaeus). See also M. Lacore, 'Du "sommeil sans réveil" à la résurrection comme réveil', Gaia: revue interdisciplinaire sur la Grèce Archä̈que 13 (2010) 205-27.

9 [Ammonius], De adfin. voc. dif. §50 (14.3-4 Nickau). 
from sleep'). ${ }^{10}$ Grammatical rules are occasionally broken, as in Ps.-Plato's

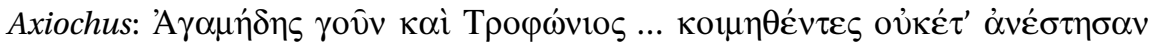
('Agamedes and Trophonius indeed going to sleep no longer rose up'). ${ }^{11}$ A text

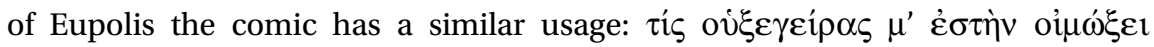

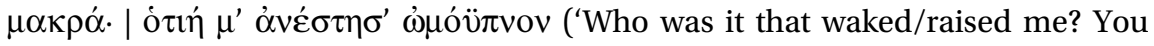
will wail aloud | because you raised [or "woke"] me from my unfinished sleep'). ${ }^{12}$ In general, it is true that classical Greek texts do not use the verb Q $v i \sigma \tau \eta \mu$ to mean 'rise (from sleep)'. Both verbs imply a physical motion upward from the state of sleep, lying down or death - in contexts where individuals are sleeping, lying down or dead.

LXX and NT usage of the verbs for resurrection has roots in classical usage. A chorus in Sophocles' Electra tells her that she will never raise her father from the

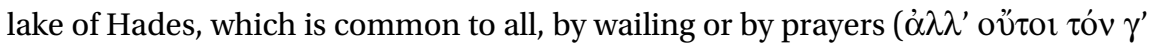

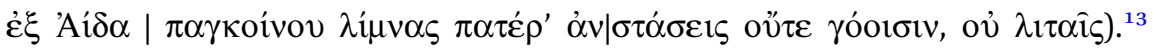
There are a number of examples of the verb used in this way in classical litera-

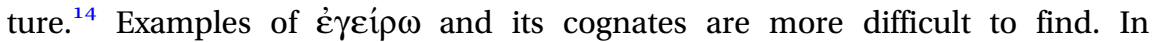
Aeschylus' Choephoroe, Orestes asks his dead father: $\hat{\alpha} \rho$ ' $\dot{\varepsilon} \xi \varepsilon \gamma \varepsilon i p \eta \imath$

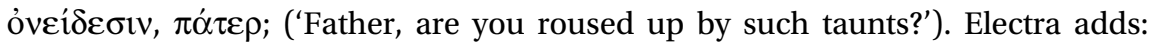

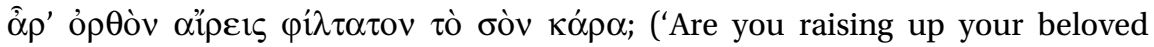
head erect?'). ${ }^{15}$ If Ammonius is correct, then both lines are essentially referring to the same motion. Apollodorus describes Heracles' raising of Theseus (who was bound near the gates of Hades) using the same verb: ó $\delta \dot{\varepsilon} \Theta \eta \sigma \varepsilon \dot{\varepsilon} \alpha \mu \grave{\varepsilon} v$

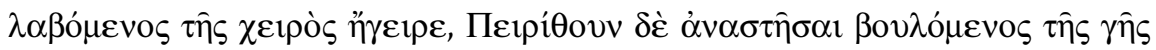

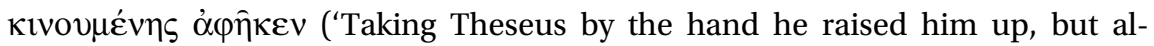
though he wanted to raise Pirithous, when the earth quaked, he let him go'). ${ }^{16}$ Theodoret presumably quotes Apollodorus (the second-century все historian) accurately, when the latter writes that Asclepius raised some who had died ( $\tau$ ivos $\tau \hat{\omega} v \tau \varepsilon \tau \varepsilon \lambda \varepsilon v \tau \eta \kappa o ́ \tau \omega \nu ~ \varepsilon ่ \gamma \varepsilon i ́ p \varepsilon ı) .{ }^{17}$ In the case of the resurrections/awakenings

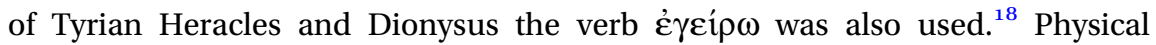
motion upward (usually 'standing up') is implied in all these texts. Clearly the

10 [Ammonius], De impr. \$48 (153.5-6 Nickau).

11 [Plato], Axiochus 10.367c.

12 Eupolis, fr. 328 Kassel-Austin $=305$ Kock. Cf. Ps.-Zonaras, Lexicon E $\$ 606$.

13 Sophocles, El. 137-9.

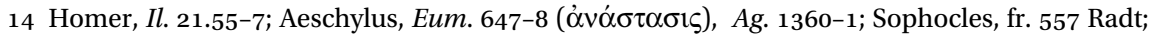
Euripides, Herc. fur. 718-19; etc.

15 Aeschylus, Cho. 495-6; the translation of Electra's question is from A. H. Sommerstein, ed. and trans., Aeschylus (LCL; 3 vols.; Cambridge, MA: Harvard University Press, 2008) II.277 (he translates غ̇ं $\varepsilon \gamma \varepsilon i \rho \eta$ with 'awakened').

16 Apollodorus, Bibl. 2.5.12. For further resurrections of Heracles, see $\$ 4.1$ below.

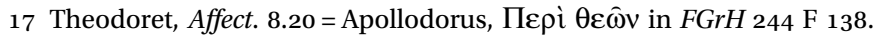

18 These will be discussed below in $\$ \$ 4.3 .2$ and 4.3.4. 
verb is not equivalent to 'exalting' (for which an ancient Greek author would use ن́

\section{Resurrection in Ancient Judaism}

From the second century вСЕ onward clear traces of resurrection can be found in some Jewish texts. ${ }^{20}$ Claudia Setzer summarises the ambivalent views of ancient Judaism admirably:

... Jewish materials from the second century $\mathrm{BCE}$ through the first century $\mathrm{CE}$ exhibit a range of understandings of the afterlife. Fairly explicit claims of bodily resurrection appear in texts like 1 Enoch $(51),{ }^{21}{ }_{2}$ Maccabees, ${ }^{22}$ 4 Q521, ${ }^{23}$ and Sibylline Oracle $4{ }^{24}$ A mix of concepts of resurrection of the body and immortality of the soul appear in 1 Enoch $(91,103),{ }^{25} 1 \mathrm{QH}^{26}{ }^{26}$ Ezra, ${ }^{27} 2$ Baruch ${ }^{28}$ and Pseudo-Phocylides. ${ }^{29}$ Ambiguity prevails in works that

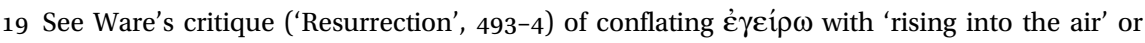
ascension.

20 J. J. Collins, 'The Afterlife in Apocalyptic Literature', Judaism in Late Antiquity: Part Four. Death, Life-After-Death, Resurrection and The World-to-Come in the Judaisms of Antiquity (ed. A. J. Avery-Peck and J. Neusner; Leiden: Brill, 2000) 119-40; C. Setzer, Resurrection of the Body in Early Judaism and Early Christianity: Doctrine, Community, and Self-definition (Leiden/Boston: Brill, 2004) 21-52; J. D. Levenson, Resurrection and the Restoration of Israel: The Ultimate Victory of the God of Life (New Haven: Yale University, 2006); and G. Nickelsburg, Resurrection, Immortality and Eternal Life in Intertestamental Judaism and Early Christianity (HTS 56; Cambridge, MA: Harvard University, 2007²).

211 Enoch 51.5 'my Chosen one will arise' (tanše' $a$ ) ... and the righteous will dwell ( yahadderu) on it (the earth)'; trans. G. W. E. Nickelsburg and J. C. VanderKam, 1 Enoch 2: A Commentary on the Book of 1 Enoch Chapters 37-82 (Hermeneia; Minneapolis: Fortress, 2012) 180.

222 Macc 7.9, 14; 12.43-4.

23 4Q521 fr. 2 col. ii + 4 l. 12 (ומיתים יחיה). Cf. A. L. A. Hogeterp, 'Belief in Resurrection and its Religious Settings in Qumran and the New Testament', Echoes from the Caves: Qumran and the New Testament (StTDJ 85; ed. F. García Martínez; Leiden: Brill 2007) 299-320, esp. 309-11.

24 Sib. Or. 4.181-3, 187-93.

25 In 1 Enoch 91.10, 'the righteous will arise (yetnašš $\bar{a}$ ) from his sleep' (not their spirits); trans. G. W. E. Nickelsburg, 1 Enoch 1: A Commentary on the Book of 1 Enoch, Chapters 1-36; 83-108 (Hermeneia; Minneapolis: Fortress, 2001) 210 (the verse may be an addition; however, $4 \mathrm{QEn}^{\mathrm{g}}$ ar $=4 \mathrm{Q} 212$ fr. 1 col. ii 1.13 apparently has the text). Cf. M. Black in consultation with J. VanderKam, The Book of Enoch or I Enoch: A New English Edition with Commentary and Textual Notes (SVTP 7; Leiden: Brill, 1985) 84, 282 ('i.e., in the resurrection'). In 103.34, however, spirits 'will live' (yahayyewu); Nickelsburg, 1 Enoch 1, 523 calls this 'revivification'. 26 Possibly $1 \mathrm{QH}^{\mathrm{a}}$ col. 14 l. 37, col. 19 1. 15. G. Stemberger, Der Leib der Auferstehung: Studien zur Anthropologie und Eschatologie des palästinensischen Judentums im neutestamentlichen Zeitalter (AnBib 56; Rome: Biblical Institute, 1972) 3 believes resurrection is probably present in the Hodayoth.

274 Ezra 7.31-2 (bodies and souls; et promptuaria reddent quae eis commendatae sunt animae).

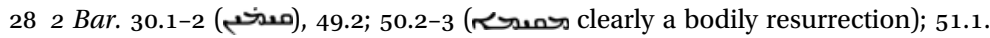

29 Ps.-Phocylides 103-15. 
nevertheless imply resurrection, such as 'the Book of the Watchers' [1-36] in 1 Enoch, The Testament of Judah, ${ }^{30}$ Psalms of Solomon, ${ }^{31}$ and CD 2:7-12. ${ }^{32}$

Ironically, the sinners taunt the righteous with the concept of the resurrection of

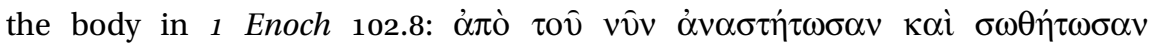
('Henceforth let them arise and be saved') - and then they proceed to deny its reality. ${ }^{33}$ Daniel 12 should be added to the list, despite the reservations of some. ${ }^{34}$ The Greek translations clearly indicate physical resurrection (Dan 12.2 LXX: $\alpha v \alpha \sigma \tau \eta \dot{\sigma o v} \alpha \alpha$; Theod.: $\dot{\varepsilon} \xi \varepsilon \gamma \varepsilon \rho \theta \dot{\eta} \sigma o v \tau \alpha \mathrm{l})$. John J. Collins classifies the view of afterlife in Jub. 23.26-31 as 'resurrection, or exaltation, of the spirit' to heaven. ${ }^{35} J u b .23 .30$, however, only asserts that the Lord's servants 'will rise $(\text { yetnašs } u)^{36}$ and see great peace', and the phrase is a reference to the 'prosperity of the living not the resurrection of the dead'. ${ }^{37}$ 'Exaltation of the spirit' is acceptable in certain cases, ${ }^{38}$ but 'resurrection of the spirit' is a category mistake, ${ }^{39}$ not appropriate for Jewish or pagan texts, as a close analysis of the verbs for resurrec-

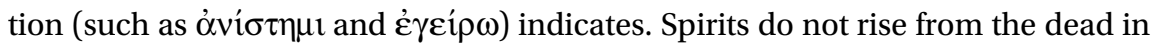
ancient Judaism, people do.

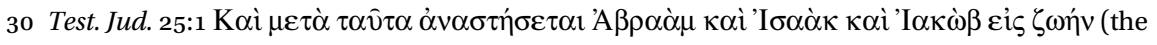
verb's use indicates bodily resurrection).

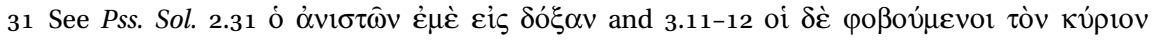

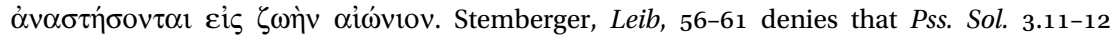
refers to resurrection. But see P. M. Sprinkle, Law and Life: The Interpretation of Leviticus 18:5 in Early Judaism and Paul (WUNT II/241; Tübingen: Mohr Siebeck, 2008) 89-90. The verb's Greek usage ( $\alpha v \alpha \sigma \tau \eta \dot{\eta} \sigma o v \tau \alpha 1)$ is enough to show that it refers to physical resurrection.

32 Setzer, Resurrection, 18. She admits (ibid., 14) that CD 2.7-13 is thoroughly ambiguous.

33 Cf. the translation and comment in Nickelsburg, 1 Enoch 1, 511, 520.

34 A convincing defence of bodily resurrection may be found in A. Chester, Future Hope and Present Reality, vol. I: Eschatology and Transformation in the Hebrew Bible (WUNT 293; Tübingen: Mohr Siebeck, 2012) 291-5. The Hebrew verb in Dan 12.2 (יקיצו) should be compared with the verb used for Gehazi's failure to raise the dead boy in 2 Kings 4.31, who showed no signs of waking/rising (לא הקיץ), translated in 4 Reg 4.31 with the very material

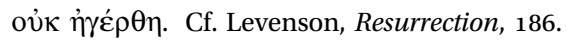

35 Collins, 'Afterlife', 124.

36 Cf. C. F. A. Dillman, Lexicon linguae Aethiopicae (Leipzig: Weigel 1865) 637 s.v. tanše’a (where it is clear that the verb has many other meanings besides references to resurrection).

37 Trans. T. R. Hanneken, The Subversion of the Apocalypses in the Book of Jubilees (Atlanta: SBL, 2012) 160 (his comment). Hanneken notes that the dead are 'aware of the restoration' but do not participate in it in 23.31. Cf. P. Volz, Die Eschatologie der jüdischen Gemeinde im neutestamentlichen Zeitalter nach den Quellen der rabbinischen, apokalyptischen und apokryphen Literatur dargestellt (Tübingen: Mohr Siebeck, 1934) 29.

38 E.g. 1 Enoch 103.3-4; Collins, 'Afterlife', 124.

39 A concept introduced by G. Ryle, The Concept of Mind (New York: Hutchinson, 1949) 16 (repr. University of Chicago Press, 2000). 


\section{Resurrections in Paganism}

No cultural encyclopedia of resurrection in antiquity would be complete without a review of the traditions in paganism.

\subsection{Resurrections Performed by Asclepius, Polyidus and Heracles}

Asclepius, Polyidus and Heracles were known for their abilities to raise individuals from the dead. Philodemus (ca. 110-40/35 BCE), ${ }^{40}$ in his treatise $O n$ Piety, has a tradition of Asclepius' resurrections:

Zeus struck down Asclepius with a thunderbolt, as the one who wrote the Naupactica [Hesiod's era] affirms and Telestes $\left[4^{\text {th }}\right.$ C. BCE] in the Asclepius and the lyric poet Cinesias [ca. 450-390 BCE], because after being entreated by Artemis, he raised Hippolytus [from the dead] (ö[ $\tau \imath \tau o ̀] \nu ~ ' I \pi \pi o ́ \lambda v \tau o v$

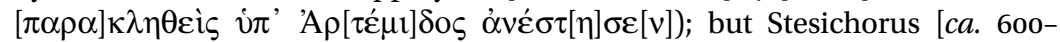
$555 \mathrm{BCE}]$ in the Eriphyle wrote that it was because of Capaneus and Lycurgus. ${ }^{41}$

Ps.-Eratosthenes (second century $\mathrm{CE}$ ) notes that Asclepius' transgressions included raising the dead by the art of the physician, and that his last resurrection

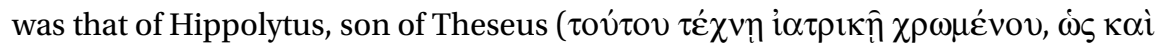

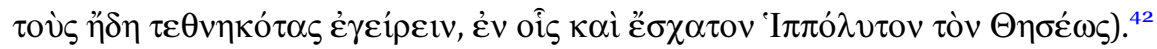
There are numerous testimonies to resurrections accomplished by Asclepius. ${ }^{43}$

Palaephetus (fourth century вСЕ?) tells the story of Glaucus as an example of an impossible event:

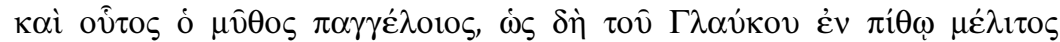

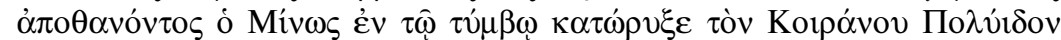

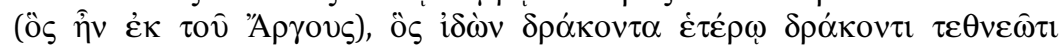

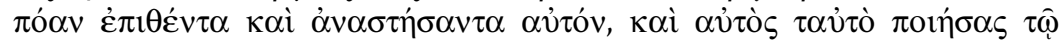

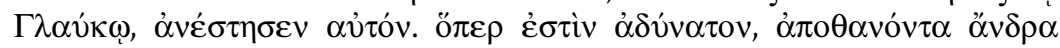

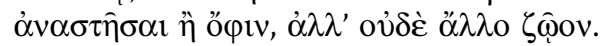

And this tale is utterly ridiculous, that when Glaucus had died in a jar of honey, Minos buried Polyidus son of Koiranos (who was from Argos) in the tomb, who seeing a serpent place an herb on another dead serpent and raise it, also did

40 Most dates below are from $O C D^{4}$.

41 Philodemus, De pietate $131(52.5-17$ Gomperz $)=$ P.Herc. 1609 col. v. Cf. E. J. Edelstein and L. Edelstein, Asclepius: Collection and Interpretation of the Testimonies (2 vols.; Baltimore/ London: Johns Hopkins University Press, 1945) T. 73.

42 Ps.-Eratosthenes, Catasterismi 1.6D (BT Mythographi Graeci III/1.7.6-13 Olivieri). Cf. K. Geus, Eratosthenes von Kyrene: Studien zur hellenistischen Kultur- und Wissenschaftsgeschichte (Munich: Beck, 2002) 211-14, who argues that Ps.-Eratosthenes' astronomical mythological

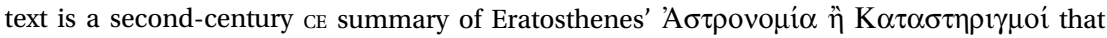
transmits a core of the original. Cf. Suda E 2898.

43 Most are in Edelstein and Edelstein, Asclepius, and I will not burden the footnotes here. 
this to Glaucus and raised him. This very thing is impossible: to raise a dead man or serpent or any other animal. ${ }^{44}$

Palaephetus proceeds to give a rational explanation for the account.

Agatharchides (second century BCE) includes Alcestis among those whom Heracles raised:

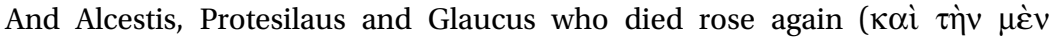

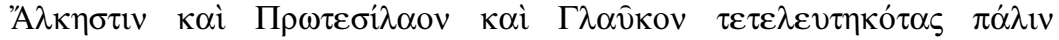

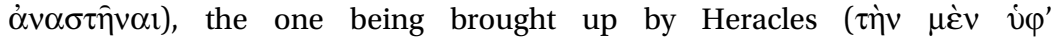

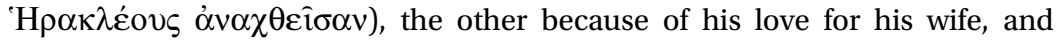
the last because of the prophecy about the one buried with him. ${ }^{45}$

In all the examples above, individuals' material bodies are raised (i.e. there is no statement that their corpses were left in tombs).

\subsection{The Resurrection Narratives of Naumachius}

Proclus (410/12-85 CE) describes certain individuals who apparently rose from the dead:

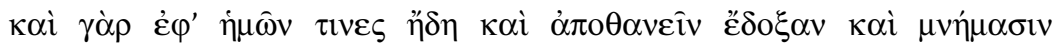

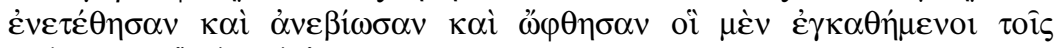

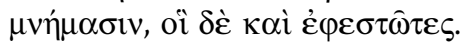

Because in our time certain individuals who were thought to have been already dead and who had been buried in their tombs came to life again and appeared (were seen), some lying on their tombs and others standing up. ${ }^{46}$

Proclus gives several examples from an individual named Naumachius:

And Naumachius of Epirus, who lived in the time of my grandparents, records that Polycritus, one of the most distinguished of the Aetolians who had obtained the office of Aetoliarch, died and came to life again in the ninth

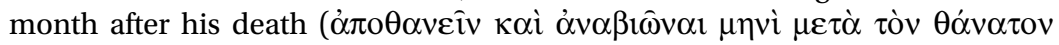
غ่vó $\tau \omega)$; and he came to the public assembly of the Aetolians and advised them on the best course of action to take concerning affairs that they were deliberating. Among the witnesses to these events were Hieron the Ephesian and

44 Palaephetus, De incredibilibus 26.

45 Agatharchides, De mari Erythraeo \$7. Cf. Photius, Bibl. 250.7, 443b (CUF Photius VII.140 Henry). Aeneas of Gaza lists many other resurrections accomplished by Heracles. Cf. Aeneas of Gaza, Theophrastus (M. E. Colonna, ed., Teofrasto (Naples: Iodice, 1958)) 63.1319 = Eudoxus fr. 372 (F. Lasserre, ed., trans. and comm., Die Fragmente des Eudoxos von Knidos (Berlin: de Gruyter, 1966) 126).

46 Proclus, In Platon. rem publ. 614b (II.113 Kroll). I have consulted the translations in A. J. Festugière, Proclus: Commentaire sur la République, vol. III (Paris: Vrin, 1970). 
other historians who wrote about what happened to Antigonus the king and other friends of theirs who were not present during the events. ${ }^{47}$

It is a bodily resurrection.

Proclus quotes Naumachius for the account of another individual named Eurynous from Nicopolis:

But there was not only this individual (Polycritus). In Nicopolis, among those who did not live long ago, a certain person named Eurynous experienced the same thing. After being buried by his relatives outside the city, he returned

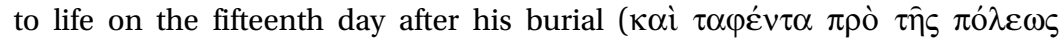

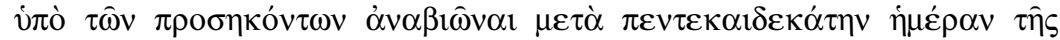
$\tau \alpha \varphi \hat{\eta} \varsigma)$ and said that he had seen and heard many amazing things under the earth but that he had been ordered to keep everything secret (unspoken). And he lived not a short time afterwards and appeared to be more just after

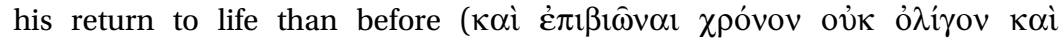

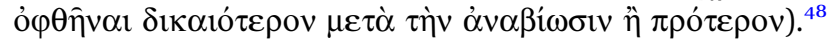

Eurynous rises again and leaves his tomb.

Naumachius continues with a description of an individual named Rufus of Philippi who lived near his own time:

He adds still another account of an individual who, as he says, lived recently: a certain Rufus from Philippi in Macedonia who had been honoured with the revered high priesthood of Thessalonica. For when this person died he came to life again on the third day and coming to life said that he had been sent

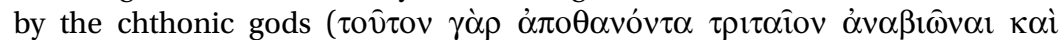

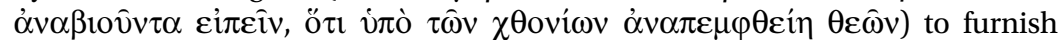
certain spectacles for the people, which he had happened to promise, and living until their completion he immediately died. ${ }^{49}$

Naumachius, in Proclus' excerpts, gives no explanation for these events other than the hint that the 'chthonic gods' were responsible. Proclus himself believes they were near-death experiences, in which a spark of life remained in the apparently dead bodies. ${ }^{50}$

47 Proclus, In Platon. rem publ. 614b (II.115 Kroll). In Phlegon's (De mir. 2.1.6-7) version, Polycritus describes himself a 'ghost' $(\varphi \alpha ́ \sigma \mu \alpha \tau)$ and 'dead in body' ( $\tau \hat{\omega} \mu \grave{\varepsilon} \nu \sigma \omega \dot{\omega} \mu \tau \imath$ $\tau \dot{\varepsilon} \theta v \eta \kappa \alpha)$.

48 Proclus, In Platon. rem publ. 614 b (II.115 Kroll).

49 Proclus, In Platon. rem publ. 614b (II.115-16 Kroll).

50 Proclus, In Platon. rem publ. 614b (II.113 Kroll). Bremmer, The Rise and Fall, 94 includes Naumachius' account of Eurynous in his chapter on 'Near-Death Experiences', even though he translates the relevant text as 'he was seen to be much more just after his resurrection than before'. 


\subsection{Resurrections of Greco-Roman Divinities}

The discussions below must necessarily be short, but that should not detract from their accuracy.

\subsubsection{Osiris and Horus}

The most ancient depiction of the resurrection of a divinity is that of Osiris. The Pyramid Texts are unambiguous. Resuscitation is clearly expressed in this Pyramid Text:

Osiris awakes: the god once slack rouses, the god stands up, the god takes control of his body. This Pepi (II) ${ }^{51}$ Neferkare awakes; the god once slack rouses, the god stands up, the god takes control of his body. Horus stands up that he might array this Pepi Neferkare with the woven cloth that comes from him ... ${ }^{52}$

Apparently the Netherworld (Dewat), where Osiris reigns, is occasionally located in the sky. ${ }^{53}$ In a Ptolemaic-Roman temple at Denderah, Osiris is depicted in several pertinent scenes (see Fig. 1): in one he is lying dead and being 'mourned by Isis and Nephtys' (Fig. 1a). In another he is depicted 'rising from his bed in a floating position' (Fig. 1b). ${ }^{54}$ Plutarch, who identifies Dionysus and Osiris, refers to the dismemberment, resurrection and rebirth of Osiris:

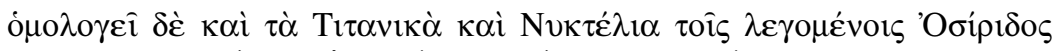

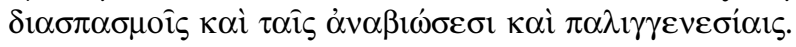

The narratives of the Titans and of the Night Festivals (the Titanika and Nuktelia) correspond with the so-called dismemberments, returns to life and rebirths of Osiris. ${ }^{55}$

Although Plutarch uses plurals, he probably does not intend the reader to understand a cyclical series of dismemberments and so forth. J. Gwyn Griffiths believes that the rebirth may refer to Osiris' incarnation (reincarnation) as Apis, where Apis is conceived as being the 'image of the soul of Osiris' ${ }^{56}$ It is bodily resurrection, and there is no question of Osiris' body being left in the tomb.

51 He ruled $c a$. 2246-2152 всE.

52 Pyramid Texts, Recitation 690; trans. J. P. Allen, The Ancient Egyptian Pyramid Texts (Atlanta: SBL, 2015 ${ }^{2}$ ) 287 (a text referred to by J. G. Griffiths, The Origins of Osiris and his Cult (SHR 40; Leiden: Brill, 1980) 64).

53 Pyramid Texts, Recitation 466; trans. Allen, Pyramid, 128.

54 T. N. D. Mettinger, The Riddle of Resurrection: 'Dying and Rising Gods' in the Ancient Near East (CB.OT 50; Stockholm: Almqvist, 2001) 172-3 (with images).

55 Plutarch, Is. Os. 35.364f.

56 Plutarch, Is. Os. 35.364e-f. Cf. J. G. Griffiths, ed., trans. and comm., Plutarch's De Iside et Osiride (Cardiff: University of Wales, 1970) 363-5, 435 (with reference to Is. Os. 20.59b and 43.368b-c). Griffiths (ibid., 434) compares this text with De E ap. Delph. 9.389A. 
(a)

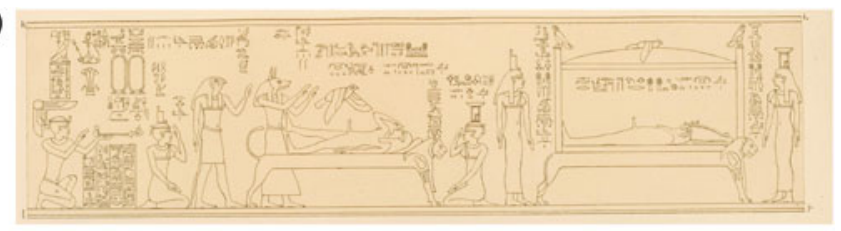

(b)

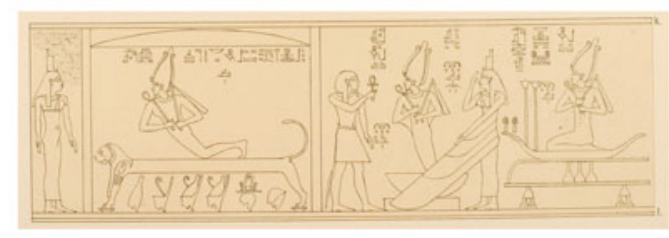

Figure 1. Depictions of Osiris from a Ptolemaic-Roman temple at Denderah: (a). Osiris being mourned by Isis and Nephtys; (b). The resurrection of Osiris. Drawing from A. Mariette, Dendérah, vol. IV (Paris: A. Franck, 1873) Plate 9o, digitally scanned by the Universitätsbibliothek Heidelberg and available at: http://digi.ub.uni-heidelberg.de/diglit/mariette1873bd4/ 096 .

According to Diodorus Siculus, Isis raised Horus from the dead using a 'medicine of immortality':

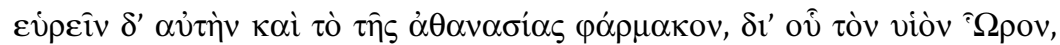

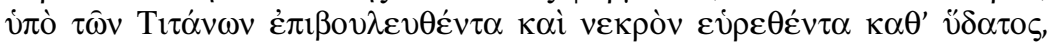

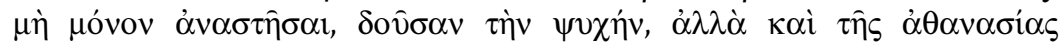
$\pi \mathrm{o} \hat{\sigma} \sigma \alpha \iota \mu \varepsilon \tau \alpha \lambda \alpha \beta \varepsilon \hat{\imath}$.

Furthermore, she discovered also the drug which gives immortality, by means of which she not only raised from the dead her son Horus, who had been the object of plots on the part of Titans and had been found dead under the water, giving him his soul again, but also made him immortal. ${ }^{57}$

Horus rises bodily.

\subsubsection{Dionysus}

Although there are many Dionysi, ${ }^{58}$ there exist several intriguing versions of his resurrection after the dismemberment he suffered at the hands of the Titans. In one version (the non-Orphic) his members were put back together.

57 Diod. Sic. 1.25.6; trans. C. H. Oldfather, ed. and trans., Diodorus Siculus: Library of History

(LCL; 12 vols.; Cambridge, MA: Harvard University Press, 1933-67) I.81.

58 Wedderburn, Baptism, 193, with reference to Cicero, Nat. D. 3.58 Dionysos multos habemus ... 


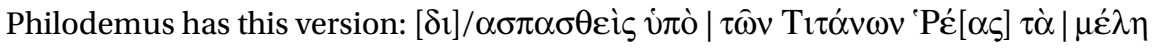
$\sigma \cup v \theta \varepsilon[i \sigma \eta \zeta]$ | $\dot{v} \varepsilon \beta i ́ \omega[1]$ ('torn apart by the Titans, Rhea put his members together, and he returned to life'). ${ }^{59}$ Plutarch refers to Thyiads (female devotees) who awaken/raise the Liknites (God of the Mystic Basket):

Similar agreement is found too in the tales about their sepulchres ( $\tau \grave{\alpha} \varsigma \tau \alpha \varphi \grave{\alpha}$ ). The Egyptians, as has been stated, point out the tombs $(\theta \dot{\eta} \kappa \alpha \varsigma)$ of Osiris in many places, and the people of Delphi believe that the remains of Dionysus rest with them close beside the oracle; and the Holy Ones offer a secret sacrifice in the shrine of Apollo whenever the (female) devotees of Dionysus wake the

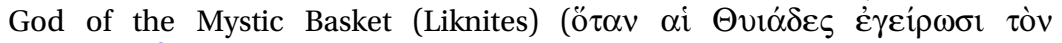

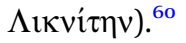

Martin Nilsson argues that the passage gives one the impression 'that Plutarch has in mind not the awakening of a sleeping god but the raising of him from the dead'. ${ }^{61}$

The people and council of Rhodes (after $212 \mathrm{CE}$ ) honoured a priest of Bacchus/Dionysus who had given 360 drachmas to the individual charged with 'waking' Dionysus:

... having given to the hydraulic organist who wakes the god ( $\tau \hat{\omega} \dot{\varepsilon} \pi \varepsilon \gamma \varepsilon i \rho \rho \nu \tau \imath$

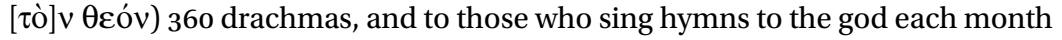

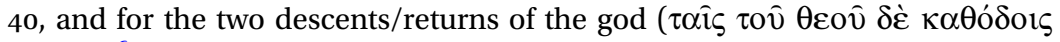
$\delta v \sigma i) \ldots{ }^{62}$

Nilsson believes that the two ascents are Dionysus' 'rebirth after his being dismembered by the Titans and his ascent with Semele'. ${ }^{63}$ Given the tradition of Dionysus' resurrection, it is doubtful that the reference here is merely to a ceremony to reanimate a statue, particularly since the text refers to his descents/ ascents.

59 Philodemus, De pietate 3.44.4-8 (16 Gomperz)=P.Herc. 247 col. III. Cf. Diod. Sic. 3.62.6; Origen, C. Cels. 4.17 ('being torn apart by them (the Titans), and after all that being put back together and apparently coming back to life and ascending into heaven (oiovei

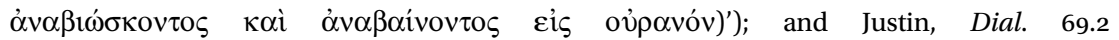

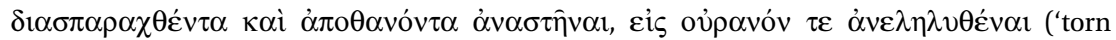
apart, and dying, he rose again, and ascended into heaven').

60 Plutarch, Is. Os. 35.364f-365a; trans. F. C. Babbitt et al., eds. and trans., Plutarch: Moralia (LCL; 15 vols.; Cambridge, MA: Harvard University Press, 1927-69) v.87. M. Nilsson, The Dionysiac Mysteries of the Hellenistic and Roman Age (New York: Arno, 1975) 38-41 was apparently sceptical of the antiquity of the tradition.

61 Nilsson, Dionysiac Mysteries, 39-40.

62 REG 17 (1904) 203, 1b.

63 Nilsson, Dionysiac Mysteries, 41. Pausanias 2.31.2 recounts Dionysus' rescue of Semele from Hades. 
In the Orphic version Athena saves Dionysus' heart, from which his body is refashioned. ${ }^{64}$ Proclus writes that Athena preserves Dionysus 'immaculate' ( $\delta$ iò

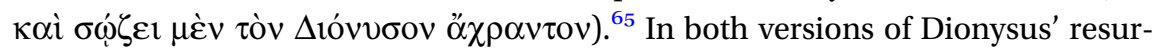
rection or awakening it is his body that rises (even if it had to be remade from his heart). Philodemus, for example, makes it clear that his body was put back together. This conception of Dionysus' resurrected body is patently material.

\subsubsection{Adonis}

Theocritus (third century вСE), in his idyll on the Adonia in Alexandria,

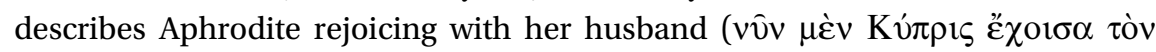

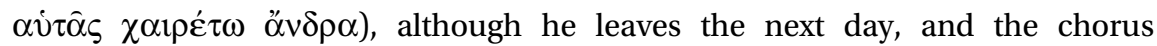
mourns: ${ }^{66}$

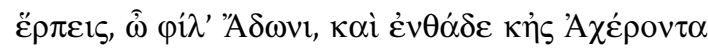

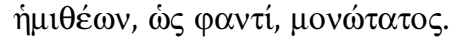

You alone of the demigods, as they say, beloved Adonis, go both here (to this world) and also to Acheron. ${ }^{67}$

The scholiast to Theocritus writes that Adonis spends six months with Aphrodite and six months with Persephone:

It is said that after death Adonis spent six months in the arms of Aphrodite and

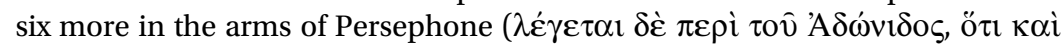

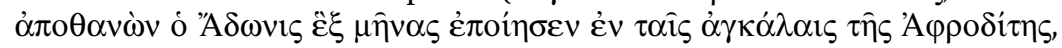

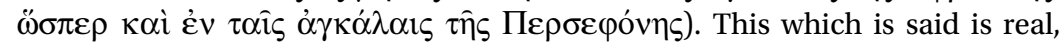
because Adonis, that is, the grain which is sown, passes six months in the ground after the sowing, and Aphrodite has him for six months, which is the mildness of the open air. And after that people harvest him. ${ }^{68}$

64 See M. L. West, The Orphic Poems (Oxford: Oxford University Press, 1983) 151 and 161-2. Firmicus Maternus, Err. 6.4; Proclus, In Plat. Tim. comm. 35a (II.145 Diehl); Clement of Alexandria, Prot. 2.18.1-2 (the heart still palpitates, but Apollo buries the limbs of Dionysus in Parnassus (cf. the reference to Orpheus in 2.17.2)); Scholia in Lycophr. 355; and Proclus,

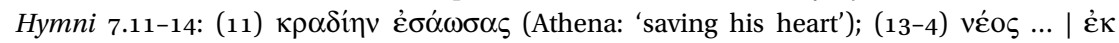

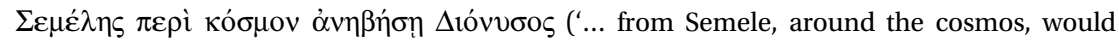
grow again a new Dionysus').

65 Proclus, In Plat. Tim. comm. 24d (BT I.168 Diehl). Cf. Proclus, In Plat. Cratyl. 406bc, \$182 (BT

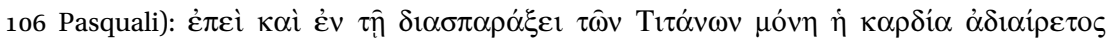

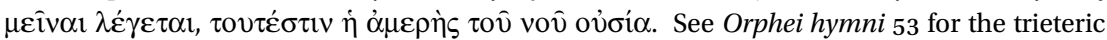

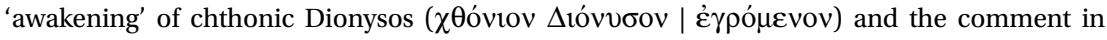
Nilsson, Dionysiac Mysteries, 40.

66 Theocritus, Id. 15.129-43.

67 Theocritus, $I d$. 15.136-7.

68 Schol. in Theocr. Id. 3.48d. 
Lucian apparently witnessed this ritual in the temple of Byblian Aphrodite:

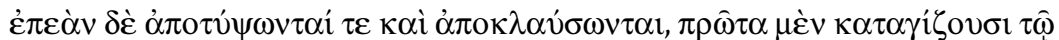

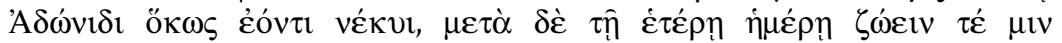

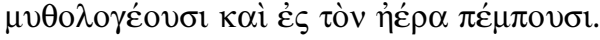

After they have finished beating their breasts and lamenting, they first make offerings to Adonis as to the dead, and afterwards, on the next day, they claim [or 'recite the myth'] that he lives and send him into the air. ${ }^{69}$

Jane L. Lightfoot draws attention to the parallel between Ps.-Nonnos's

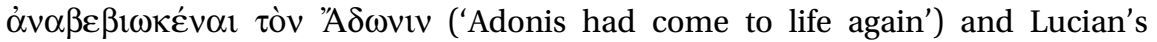

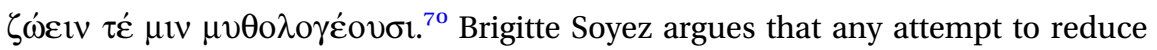
'he is alive' to a theatrical scene, the erection of a pillar symbolising Adonis, irony or a mystical illusion is simply a fundamental misconstrual of the meaning of the text. ${ }^{71}$ Lightfoot thinks that 'alive' refers to the 'sharing arrangement with six months in either world'. ${ }^{72}$ Adonis' body is physically present with Persephone and Aphrodite and this corresponds closely with resurrected bodies in Christian tradition.

\subsubsection{Tyrian Heracles}

A number of individuals in the ancient Mediterranean identified Tyrian Heracles with Melqart. ${ }^{73}$ An illuminating passage from Josephus refers to Menander's account of Hiram of Tyre's reign: ${ }^{74}$

69 Lucian, De dea Syria 6; trans. J. L. Lightfoot, ed., trans. and comm., Lucian: On the Syrian Goddess (Oxford: Oxford University Press, 2003) 251. After $\pi \varepsilon ́ \mu \pi 0 v \sigma 1$ Lightfoot, ibid., 250 inserts a period with H. Seyrig, 'La résurrection d'Adonis et le texte de Lucien', Syria 49 (1972) 97-100, esp. 99. Lightfoot (pp. 184-208) convincingly defends the authorship of Lucian. 70 Lightfoot, Lucian, 311. See Ps.-Nonnos, Scholia Mythologica Oratio 5, historia 5 (CCSG 27.26970 Nimmo Smith).

71 B. Soyez, Byblos et la fête des Adonies (EPRO 60; Leiden: Brill, 1977) 38, with reference to G. Roux, 'Sur deux textes relatifs à Adonis', $R P h 41$ (1967) 259-64, esp. 262-4.

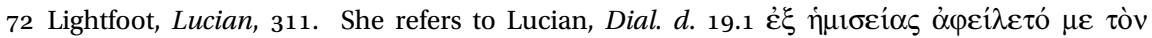

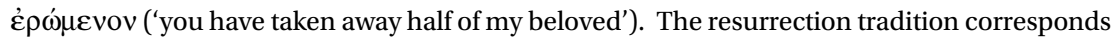
to later Christian witnesses (some only mention the finding of Adonis): Origen, Sel. in Ezech.

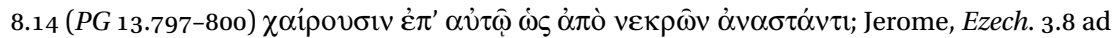
8.14 (CCSL 75.99.285-301 Glorie); Cyril of Alexandria, Is. 18.1-2 (PG 70.441); Procopius, Is. 18.2 (PG 87/2.2140). Cf. $P G M$ iv.2902-3.

73 See e.g. the bilingual inscription from second century всЕ in Malta that mentions Heracles and Melqart in Greek and Phoenician. M. G. G. Amadasi, Le iscrizioni fenicie e puniche delle colonie in Occidente (Roma: Istituto di studi del Vicino Oriente, 1967) \$1 and 1 bis, pp. $15-16=I G$ xIv.600.

74 On Menander of Ephesus, cf. J. M. G. Barclay, trans. and comm., Flavius Josephus: Translation and Commentary, vol. x: Against Apion (Leiden: Brill, 2007) 72 (his date and identity are un-

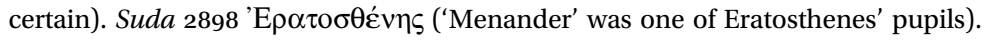


Moreover he went off and cut timber from the mountain called Libanos for the roofs of the temples, and pulled down the ancient temples and erected new ones to Heracles and Astarte; and he was the first to celebrate the awakening

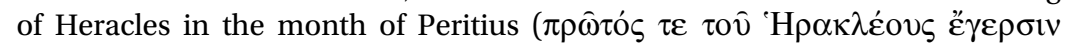

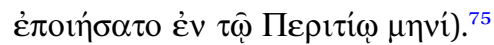

There is a parallel text in the Contra Apionem:

He demolished ancient temples and built new ones, both to Heracles and to Astarte. He initiated the 'Awakening' of Heracles, in the month of Peritios

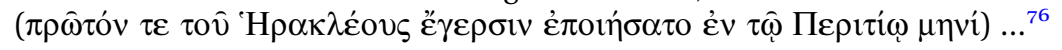

John M. G. Barclay notes that the Latin translator and others have understood the text to mean '"erection" of a temple' ${ }^{77} \mathrm{He}$ argues that 'it is not clear why Heracles' temple should be so singled out (L wrongly adds a reference to Astarte's as well ...) nor why it should be dated so precisely. Menander is probably referring to the institution of an annual festival of the "Awakening" of the God ... ${ }^{78}$ 'Resuscitation' or 'resurrection' would probably be good translations for है $\gamma \varepsilon \rho \sigma \mathrm{v}$ in the texts in Josephus. ${ }^{79}$

An inscription is relevant, which mentions an individual named Martas from

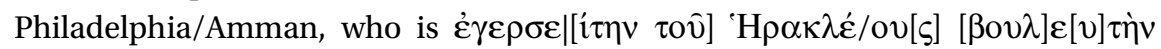
$\kappa \alpha i \mid \pi \rho[o ́ \varepsilon \delta \rho o] v$ ('resuscitator of Heracles, councillor and proedros (presi-

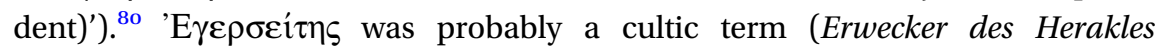

75 Josephus, A.J. 8.145-6=FGrH 783 F1; trans. H. St. J. Thackeray, R. Marcus et al., eds. and trans., Josephus: Jewish Antiquities (LCL; 10 vols.; Cambridge, MA: Harvard University Press, 1926-65) v.649-51 (Marcus).

76 Josephus, C. Ap. 1.118-19; trans. Barclay, Josephus, 73.

77 Barclay, Josephus, 73. Cf. Cassiodorus, Ios. c. Ap. 1.18.119 (fecit erectionem mense Peritio; CSEL 37.27.1 Boysen). Thackeray (Thackery, Marcus et al., Josephus, I.211) also translated the text

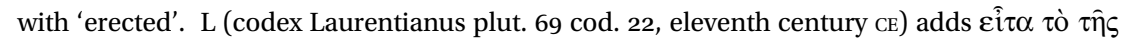

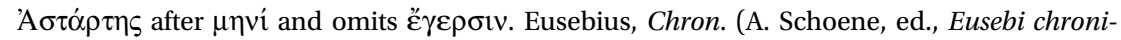

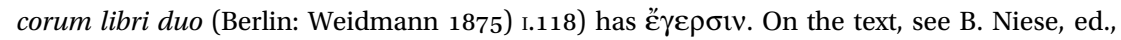
Flavii Iosephi Opera, vol. v (Berlin: Weidmann 1889) 21, apparatus criticus. Niese retains L's $\pi \rho \hat{\omega} \tau o v$ (an adverbial use).

78 Barclay, Josephus, 73-4, with reference to Athenaeus, Deipn. 9.392DE and 1 Kings 18.27-8. Mettinger, Riddle, 90 makes a similar argument: 'it would be nonsensical to say that Hiram was the first who built the temple $\mathrm{X}$ in the month of $\mathrm{Y}$, while it makes excellent sense to say that the king was the first to celebrate a certain festival in a certain month'. See the extensive analysis by C. Clermont-Ganneau, 'L'Égersis d'Héraclès et le réveil des dieux', Recueil d'archéologie orientale 8 (1924) 149-67.

79 É. Lipiński, 'La fête de l'ensevelissement et de la résurrection de Melqart', Actes de la Xvıe rencontre assyriologique internationale (Ham-sure-Heure: Comité belge de recherches en Mesopotamie, 1970) 30-58, esp. 30 translates the word as 'resurrection'.

80 IGLSyr xxi/2.29. Lipiński, 'La fête', 31, 56 translates the word as 'resuscitator' as does C. Bonnet, Melqart: Cultes et mythes de l'Héraclès tyrien en Méditerranée (Studia Phoenicia 8; Leuven: Peeters, 1988) 144-8 (on the proper reconstruction and interpretation of the offices 
'awakener of Heracles') and not a term meaning 'temple constructor'. Corinne Bonnet argues that each year in February and March there was a festival of Egersis, which comprised the burning of Melqart (Tyrian Heracles), the subsequent mourning, and his awakening or resurrection. ${ }^{81}$ If this interpretation

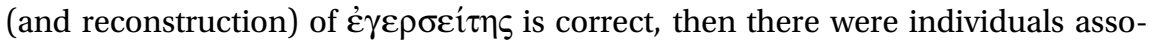
ciated with the resuscitation of Tyrian Heracles/Melqart.

It is probable that Eudoxus of Cnidus' reference to the resurrection of Tyrian Heracles illuminates the festival:

Eudoxus of Cnidus, in the first book of his descriptive geography of the earth, says that the Phoenicians sacrifice quails to Heracles, because when Heracles, the son of Asteria and Zeus, was going to Libya he was killed by Typhon. But when Iolaus brought him a quail and set it near him, he smelled it and

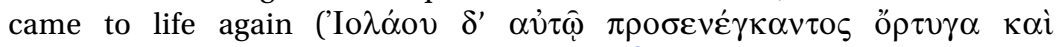
$\pi \rho \circ \sigma \alpha \gamma \alpha \gamma o ́ v \tau o \varsigma$ ó $\sigma \varphi \rho \alpha v \theta \dot{\varepsilon} v \tau \alpha \dot{\alpha} v \alpha \beta 1 \hat{\omega} v \alpha \mathrm{l}) .{ }^{82}$

'A $v \alpha \beta i \omega v \alpha \iota$ in context clearly implies that Heracles was raised from the dead. Eudoxus' account is undeniably of a material body. Menander and the inscriptions that mention an official who was the 'raiser/awakener of Heracles' also imply that Heracles' body is the object of the rituals.

\subsubsection{Attis}

The narratives of a resurrection of Attis are late, at best. In Pausanias' (second century $\mathrm{CE}$ ) Lydian version of the Attis myth, Attis is either killed by a boar or goes mad during a wedding and castrates himself when Agdistis, in love with Attis, interrupts the youth's wedding:

But Agdistis repented of what he had done to Attis, and persuaded Zeus to grant that the body of Attis should neither rot at all nor decay $\left(\mu \eta^{\prime} \tau \varepsilon \sigma \eta^{\prime} \pi \varepsilon \sigma \theta \alpha i \tau\right.$

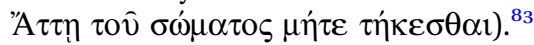

listed). Cf. Mettinger, Riddle, 90-1. An inscription from Ramlah also mentions an 'awakener/

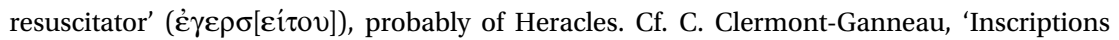
grecques de Palestine', Recueil d'archéologie orientale 7 (1906) 174-8, esp. 175; idem, 'L'inscription grecque d'Amman', Recueil d'archéologie orientale 8 (1924) 121-5, esp. 125; Bonnet, Melqart, 131-2. Lipiński, 'La fête', 56-7 notes that the Ramlah inscription refers to the cult of Heracles, because of the function (resuscitator).

81 Bonnet, Melqart, 104-13.

82 Athenaeus, Deipn. 9.392DE = Eudoxus, fr. 284a Lasserre. Cf. Zenobius (second century CE), Epit. 5.56 = Eudoxus, fr. 284b Lasserre.

83 Pausanias 7.17.10-12 (text from 12); trans. W. H. S. Jones, ed. and trans., Pausanias: Description of Greece (LCL; 4 vols.; Cambridge, MA: Harvard University Press, 1918-35) III.269. 
In Arnobius' version of the myth, which is presumably based on Timotheus ('the Athenian Eumolpid'), an author who wrote ca. 300 BCE, only Attis' little finger survives death: ${ }^{84}$

Jupiter refuses Acdestis' request that Attis might come back to life (Iuppiter rogatus ab Acdesti ut Attis revivesceret non sinit). But what is possible by concession of fate, this he grants without objecting: that his body should not decay, that his hair should ever grow, that the very smallest of his fingers should live and alone react by continued motion (ne corpus eius putrescat, crescant ut comae semper, digitorum ut minimissimus vivat et perpetuo solus agitetur e motu). Satisfied with these favors, Acdestis, it is said, consecrated the body in Pessinus, and honored it with annual rites and with a sacred ministry. ${ }^{85}$

Smith notes the 'second to fourth century AD reinterpretation, within some of the "mystery" cults, of archaic locative traditions of dead deities in new experimental modes which appear to testify to these deities returning to life. In the case of Attis, there are only scattered hints of this process. ${ }^{86}$

Hippolytus, in his discussion of the Naassenes, affirms a resurrection for Attis (who is called 'Pappas' in the text). ${ }^{87}$ The anonymous source ('he') is a 'Gnostic' ${ }^{88}$ author whom Hippolytus does not name:

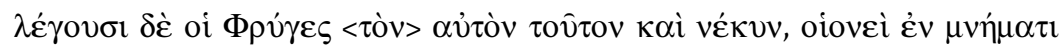

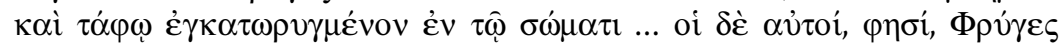

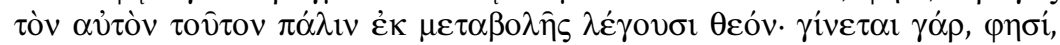

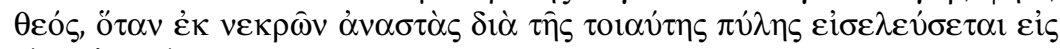

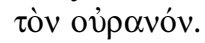

But the Phrygians say that the same one is also a 'corpse', having been buried in the body as in a monument or tomb ... And the same Phrygians, he says again, say that this same one is by reason of the change a god. For he becomes a god when he arises from the dead and enters into heaven through the same gate [the gate of the heavens]. ${ }^{89}$

84 See J. N. Bremmer, 'Attis: A Greek God in Anatolian Pessinous and Catullan Rome', Mnemosyne 57 (2004) 534-73, esp. 542-4 (who emphasises Alexander Polyhistor's use of Timotheus as a source; cf. FrGH 273 F 74), reprinted in his Greek Religion and Culture, the Bible and the Ancient Near East (Leiden: Brill, 2008) 267-302.

85 Arnobius, Nat. 5.7 (CSLP 256 Marchesi); trans. G. E. McCracken, trans. and comm., Arnobius of Sicca: The Case Against the Pagans (ACW 8; 2 vols.; Westminster, MD: Newman, 1949) II.417.

86 Smith, Drudgery Divine, 133.

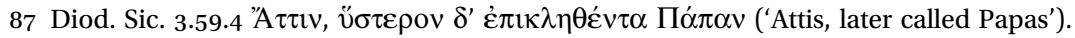

88 The cautionary quotes indicate the problematic nature of the concept.

89 Hippolytus, Haer. 5.8.23-4; trans. modified from F. Legge, Philosophumena or the Refutation of All Heresies ... (London: SPCK, 1921) 135. 
Firmicus Maternus also is a late witness to a resurrection of Attis. After describing Attis's death at the hands of Cybele, he says:

They (the Phrygians) advanced the claim that he whom they had buried a little while earlier had come to life again (Phryges ... quem paulo ante sepelierant revixisse iactarunt); and since the woman's heart burned unbearably with overweening love, they erected temples to the dead youth ... His death they interpret as the storing away of the collected seeds, his return to life as the sprouting of the scattered seeds in the annual turn of the seasons (vitam rursus quod iacta semina annuis vicibus reconduntur). ${ }^{90}$

The conclusion of Jan Bremmer has the strongest warrant: 'Attis' "resurrection" is not mentioned before the third century and seems closely connected with the rise of Christianity, just like the "resurrection" of Adonis is not mentioned before the third century'..$^{91}$ The question of analogy and genealogy in the history of religions is controversial. ${ }^{92}$ The resurrection is bodily (i.e. material) in Firmicus Maternus. The buried Attis rises again. The 'Gnostic' Phrygians of Hippolytus, however, relate the bodily resurrection of Attis to the spiritual resurrection of the pneuma-

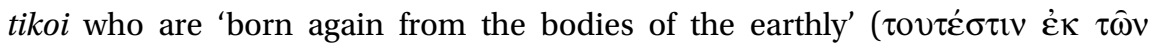

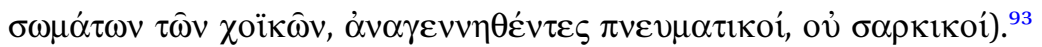

\section{Protesilaus the Hero}

Protesilaus was the first Greek hero to die in Troy. ${ }^{94}$ Philostratus, in the Heroikos (a dialogue between a Phoenician and a vinedresser in Elaious), asserts that Protesilaus returned to life twice. ${ }^{95}$ The Phoenician asks, 'Has he

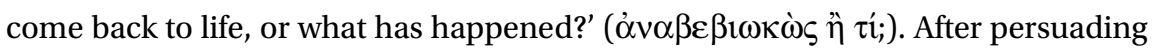
his wife to return with him to Hades, he returned to life again:

Phoen.: And yet he is said to have died after he came to life again ( $\alpha$ đo $\theta \alpha v \varepsilon \hat{\imath} v$ $\gamma \varepsilon \mu \varepsilon \tau \grave{\alpha} \tau \grave{o} \alpha \dot{\alpha} \alpha \beta \hat{\imath} v \alpha \iota \lambda \dot{\varepsilon} \gamma \varepsilon \tau \alpha \imath)$ and to have persuaded his wife to follow him.

VINEDR.: He himself also says these things. But how he returned afterwards too, he does not tell me even though I've wanted to find out for a long time. He is

90 Firmicus Maternus, Err. 3.1-2; trans. slightly modified from C. A. Forbes, trans. and annot., Firmicus Maternus: The Error of the Pagan Religions (ACW 37; New York: Newman, 1970) 47-8.

91 Bremmer, 'Attis', $547=$ Bremmer, Greek Religion, 280. I would amend this statement in the case of Attis to 'second century', the date of Lucian, who probably wrote De dea Syria.

92 Smith's Drudgery Divine is a case in point, and see the response of Bremmer ('Resurrection', $106=$ Rise and Fall, 54).

93 Hippolytus, Haer. 5.8.23.

94 Homer, $I l$. 2.695-710.

95 Philostratus, Heroik. 2.7-11. See Lucian, Dial. mort. 28.1-2. 


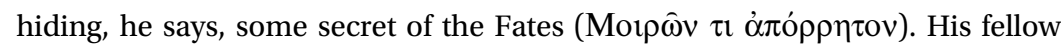
soldiers also, who were there in Troy, still appear on the plain, warlike in posture and shaking the crests of their helmets. ${ }^{96}$

Jonathan Burgess argues that it is the 'shade of Protesilaos' who 'spends time with Laodameia in Hades' and who 'appears to humans in Phthia and in Elaious' ${ }^{97}$ This is warranted given the vinedresser's assertion, when asked to explain the nature of his association with Protesilaus and his ability to foretell the future, that

[t]o be cleansed of the body is the beginning of life for divine and thus blessed

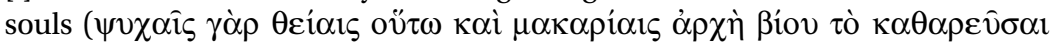
$\tau o \hat{v} \sigma \omega \dot{\mu} \alpha \tau \varsigma)$. For the gods, whose attendants they are, they then know, not by worshipping statues and conjectures, but by gaining visible association with them. And free from the body and its diseases ( $\dot{\varepsilon} \lambda \varepsilon v \dot{\theta} \theta \varepsilon \alpha \iota$ vó $\sigma \omega v \tau \varepsilon$

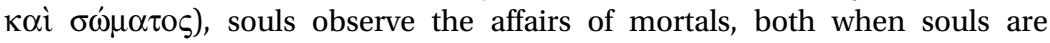
filled with prophetic skill and when the oracular power sends Bacchic frenzy upon them. ${ }^{98}$

Antonio Stramaglia describes Protesilaus and Palamedes (Heroik. 21.6) as 'souls that have been heroized' (anime eroizzate). ${ }^{99}$ This explains why the narrative of Protesilaus' return to life is consistent with his body being buried in the

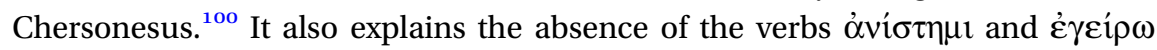
to describe Protesilaus' return to life, and the use of the more ambiguous óv $\alpha \beta$ io $\omega$ - a verb avoided by the New Testament.

\section{Conclusion}

On the basis of the semantics of $\alpha v i \sigma \tau \eta \mu \mathrm{t}$ and $\dot{\varepsilon} \gamma \varepsilon \dot{\rho} \rho \omega$ and the cultural encyclopedia of resurrected bodies, one can conclude that Paul would have assumed that the tradition about the burial of Christ and his resurrection on the third day presupposed a tradition of an empty tomb. To put it another way: Paul would have taken it for granted that the resurrection of Christ was

96 Philostratus, Heroik. 2.10-11; trans. J. K. Berenson Maclean and E. Bradshaw Aitken, Flavius Philostratus: Heroikos, trans. with intro. and notes (SBLWGRW 1; Atlanta: SBL, 2001) 9-11. Cf. 58.1-2 on the inviolable secret of how he returned to life.

97 J. S. Burgess, The Death and Afterlife of Achilles (Baltimore: Johns Hopkins University Press, 2009) 110, with reference to Heroik. 11.7-8.

98 Philostratus, Heroik. 7.3; trans. Maclean and Aitken, Philostratus: Heroikos, 19-21.

99 A. Stramaglia, Res inauditae, incredulae: storie di fantasmi nel mondo greco-latino (Bari: Levante, 1999) 317. T. Mantero, Ricerche sull'Heroikos di Filostrato (Genova: Istitute di Filologia Classica e Medioevale, 1966) 81 refers to Philostratus, Heroik. 43.3 where Protesilaus is called a daemon. I thank Professor Stramaglia for his comments to me on this problem (30 March 2015, personal communication).

100 Philostratus, Heroik. 9.1. 
inconceivable without an empty tomb. Consequently, according to the normal conventions of communication, he did not need to mention the tomb tradition.

The following objections may arise:

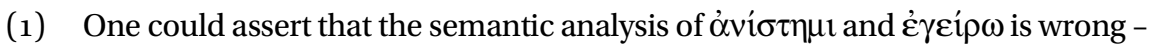
that is, the verbs do not imply physical motion upward. In this case, the burden is on the scholar in question to show that in the context of resurrec-

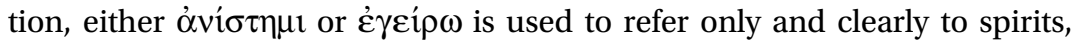
souls or astral bodies in a pagan or Jewish text. This is not to deny that there was a spiritual or metaphorical usage of resurrection words in the New Testament and early Christianity (Col 2.12; 3.1; Eph 2.5-6). The metaphorical uses in the deutero-Paulines, however, are based on the image of the resurrection of Christ.

(2) One can respond that some ancient Jews in the Second Temple period believed in a resurrection of the spirit. Again the burden is on such scholars

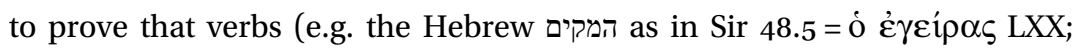
tanše' $a$ in Ethiopic; etc.) or nouns for resurrection are combined syntactically (or semantically) with terms such as 'spirit' or 'soul'. Such evidence is absent.

(3) One could argue that pagan attitudes towards resurrection are irrelevant for the understanding of the New Testament - in particular, of Paul's views in 1 Cor 15. However, Paul's readers from pagan backgrounds would have viewed resurrection (as opposed to the immortality of the soul) as bodily. In that respect, there is a certain continuity between ancient Judaism and paganism, which is of fundamental importance for understanding the New Testament in its ancient context.

(4) One could accept the truth of the three premises above and still deny the conclusion for which I have argued. After all, the argument is not deductive, but inductive. In our guild as historians one can only appeal to probability, however, and if the premises are true, then the conclusion seems unavoidable: Paul could not have conceived of a resurrection of Christ without believing that his tomb was empty. 